\title{
STUDY OF THE NICKEL SILICATES ASSOCIATED WITH THE ULTRABASIC ROCKS OF NUGGIHALLI SCHIST BELT, MYSORE STATE
}

\author{
By C. Naganna and S. G. Phene \\ (Department of Geology, Bangalore University, Bangalore) \\ Received March 18, 1968 \\ (Communicated by B. P. Radhakrishna, F.A.sc.)
}

\begin{abstract}
The occurrence of some nickel silicate minerals as encrustations along joint planes and shear zones of the chromite bearing uitrabasic rocks of Nuggihalli schist belt is described. Chemical and X-ray study shows besides amorphous nickel silicate, the presence of granierite, nepouite or nickel antigorite. The nickel minerals are secondary developed by the action of circulating waters. The source of nickel is olivine, in the structure of which $\mathrm{Ni}$ is known to be present, either as camouflaged or captured ion.
\end{abstract}

\section{INTRODUCTION}

IN a brief note by one of the authors of this paper (Naganna, 1965) the occurrence of garnierite in the ultrabasic rocks of Nuggihalli schist belt was reported and it was indicated that the mineral has been formed by secondary processes. The object of the present paper is to give the results of the detailed chemical and X-ray investigations done on the material systematically collected from different horizons at "A" pit of the Byrapur chromite mines and to discuss the origin of the nickel minerals in this area in the light of these results.

\section{Geological Setting and the Mode of Occurrence of the NiCKel Minerals}

The name Nuggihalli schist belt is given to a narrow band of Dharwarian rocks composed of hornblende schist and amphibolites occurring near Nuggihalli $\left(13^{\circ} 07^{\prime}: 76^{\circ} 25^{\prime}\right)$ Hassan District. Here, the schist belt is spread over a distance of $30 \mathrm{kms}$. in a N.N.W. direction with an average width 
of about $1 \mathrm{~km}$. The ultrabasic rock mass occurring almost all along the length of this belt is considered to be instrusive into the Dharwar schists.

The "A" pit of the Byrapur chromite mines from where the samples have been drawn for the present study is situated in the centre of the Nuggihalli schist belt. Here a lensoid mass of bleached serpentinite is found enclosed by amphibolite and the " $A$ " pit is situated right on the bleached serpentinite. The serpentinite mass has been traversed by a number of high angle joints and fault planes. Besides these, there are two shear zones abutting this pit. Unaltered dunite is not seen anywhere on the surface but the bleached serpentinite gradually passes on to dunite at depth. A number of veins and joint planes traversing this rock are found filled with magnesite.

The nickel silicate minerals are not seen at the surface but start appearing at the 100 feet level and become profuse at the 150 feet level. They are found only as encrustations or as irregular mamillary crusts on walls of wet fissures. Thick concentration of these minerals is also seen in the shear zones. Secondary cryptocrystalline quartz encrustations are invariably seen with these minerals. This secondary quartz sometimes exhibits light green colour. The nickel minerals are generally green in colour; they exhibit different shades of green. In almost all cases the encrustation is seen on unaltered dunite.

\section{NiCKel Minerals}

Five samples of the hydrous nickel silicates, showing variation in colour were selected for the present study. Of these, two samples which gave very faint X-ray diffraction lines were regarded as amorphous substances; and hence they were not subjected to further investigations. The other three samples selected for study have been named $G_{1}, G_{2}$ and $G_{3}$. Besides these, the unaltered dunite on which these minerals are found as encrustations and the bleached serpentinite have been chemically investigated.

Sample $G_{1}$ was collected at 100 feet level from the wall of a wet fissure. The sample which was in the form of an encrustation has come out as a big thin plate, made up of cryptocrystalline material, light green in colour, with dull or waxy luster. By looking at the hand specimen and thin sections, it is possible to recognise it as secondary cryptocrystalline variety of quartz. Sample $G_{2}$ is also from the 100 feet level collected from a shear zone. The specimen which is bright green in colour is found mixed up with some greenish-gray and pinkish-gray material in the shear zone. Sample $\mathbf{G}_{3}$ has been collected from 150 feet level and this material is yellowish-green in 
colour. Both the samples $G_{2}$ and $G_{3}$ have dull luster. Thin sections made from both these samples exhibit light green colour in ordinary light but under crossed nicols they do not react and appear dark. However, a few small grains embedded in this material show unisotropism.

The chief physical properties of the samples are tabulated in Table I TABLE I

\begin{tabular}{clrl}
\hline Sample & \multicolumn{1}{c}{ Colour } & Hardness & Sp. Gr. \\
\hline $\mathrm{G}_{1}$ & Light green & $5-6$ & $2 \cdot 62$ \\
$\mathrm{G}_{2}$ & Bright green & $2 \cdot 5-3$ & $2 \cdot 43$ \\
$\mathrm{G}_{3}$ & Yellowish-green & $3-4$ & $2 \cdot 58$ \\
\hline
\end{tabular}

X-ray powder diffraction photographs have been taken for these samples using $\mathrm{Fe} / \mathrm{Mn}$ radiations. All the lines recorded in the X-ray powder diffraction photographs are broad and diffuse, probably on account of the poor crystallinity of the material studied. The " $d$ " spacings and the visually estimated intensities of the lines are recorded in Table II.

TABLE II

\begin{tabular}{cccccc}
\hline $\mathrm{G}_{1} d(\AA)$ & $\mathrm{I}$ & $\mathrm{G}_{2} d(\AA)$ & $\mathrm{I}$ & $\mathrm{G}_{3} d(\AA)$ & $\mathrm{I}$ \\
\hline.. &.. & 7.23 & 5 & 10.25 & 4 \\
4.24 & 3 & 4.49 & 5 & 4.55 & 10 \\
346 & 10 & 3.70 & 10 &.. &.. \\
2.30 & 3 & 2.53 & 4 & 2.68 & 5 \\
.. &.. &.. &.. & 2.42 & 4 \\
1.82 & 7 & 1.82 & 2 & 1.73 & 1 \\
1.54 & 7 & 1.51 & 2 & 1.53 & 6 \\
1.39 & 6 & 1.32 & 2 & 1.31 & 3 \\
1.38 & 6 &.. &.. &.. &. \\
\hline
\end{tabular}


In Table III the results of the chemical analyses are given for samples $G_{2}$ and $G_{3}$.

TABLE III

\begin{tabular}{|c|c|c|c|}
\hline \multicolumn{2}{|l|}{ Oxide Wt. \% } & $\mathrm{G}_{2}$ & $\mathrm{G}_{3}$ \\
\hline $\mathrm{SiO}_{2}$ & . & $45 \cdot 31$ & $35 \cdot 08$ \\
\hline $\mathrm{Al}_{2} \mathrm{O}_{3}$ & .. & 0.62 & N.D. \\
\hline $\mathrm{FeO}$ and $\mathrm{Fe}_{2} \mathrm{O}_{8}$ & .. & $1 \cdot 18$ & $2 \cdot 94$ \\
\hline $\mathrm{MgO}$ & . & $18 \cdot 42$ & $16 \cdot 79$ \\
\hline $\mathrm{CaO}$ & .. & $1 \cdot 03$ & $2 \cdot 69$ \\
\hline $\mathrm{NiO}$ & .. & $21 \cdot 26$ & $24 \cdot 88$ \\
\hline $\mathrm{H}_{2} \mathrm{O}$ & .. & $12 \cdot 32$ & $16 \cdot 01$ \\
\hline Total & . & $100 \cdot 14$ & $98 \cdot 39$ \\
\hline
\end{tabular}

Analyst: C. Naganna.

\section{NOMENCLATURE}

As rightly remarked by Faust (1966) the hydrous nickel-magnesium silicates though belong to one of the oldest mineralogical families, their mineralogy is poorly understood. In literature we see so many names like chryso-prase, pimelite, nickel-gymnite, genthite, röttisite, noumeite, garnierite, nepouite, revdanskite, maufite, deweylite, etc., being used to describe the nickel-bearing hydrosilicates. Their names are not properly defined and it appears that in some cases different names have been used by different authors to describe one and the same mineral.

The problem of the nomenclature of the hydrous nickel silicates has been very well discussed by Pecora et al. (1949) and they have suggested that the name garnierite should be considered as a general term on par with such other " mineral mixture" names like : limonite, bauxite and manganese wad, etc., and this name could be used to describe the nickel minerals in general. This suggestion would be alright to describe the nickel minerals, when detailed mineralogical work is not done. In all cases where both chemical and X-ray data are available for the nickel minerals investigated, it is desirable 
to follow the nomenclature suggested by Montoya and Baur (1963). These workers, having studied the hydrous nickel silicates associated with the laterites, have tried to group the minerals studied into nickel serpentines, nickelchlorites and other related species. Such a grouping appears to be more useful than simply calling all the hydrous nickel silicates as garnierite, particularly when both chemical and X-ray data of the material studied are available.

Interpreting the data recorded in Tables I, II and III, according to Montoya and Baur (1963), it can be said that $G_{1}$ is a cryptocrystalline variety of quartz and its light green colour may be due to the presence of nickel in it. So far as the other two samples are concerned, it is rather difficult to name them. Both of them contain quite a high per cent of $\mathrm{NiO}$ and in this respect do not show any similarity to the reported chemical analyses of either nickel chlorite or nickel serpentine. Further, it is not known whether the nickel chlorite or serpentine can hold so much of $\mathrm{Ni}$, in addition to the amount of $\mathrm{Mg}$ that is present in the material studied. The " $d$ " spacings of $\mathrm{G}_{3}$ do not correspond with either nickel chlorites or nickel serpentine, but correspond well with a nickel silicate reported from New Caledonia by Montoya and Baur (1963) which has been described as a specific mineral under the name garnierite. Following this sample $G_{3}$ can be named as garnierite.

Both the chemical composition and " $d$ " spacings of $\mathrm{G}_{2}$ correspond well with the nickel mineral nepouite reported from New Caledonia (Montoya et al., 1963) except that it has a lower percentage of NiO. At the same time the " $d$ " spacings of this mineral can also stand a fair comparison with nickel-antigorite. Therefore, this sample could be either nepouite or nickel antigorite.

\section{ORIGIN}

$\mathrm{Ni}$ is known to get separated from a cooling magma at the earlier stages of crystallization and hence known to be a common constituent of the ultrabasic rocks. Since the ionic radii of $\mathrm{Ni}$ and $\mathrm{Mg}$ are so close $\left(\mathrm{Mg}^{+2}=\mathbf{0 . 6 6}\right.$ $\AA, \mathrm{Ni}^{+2}=0.69 \AA$ ), there appears to be complete replaceability between these two elements, and $\mathrm{Ni}$ can be present in the structure of olivine replacing Mg. The unaltered dunite occurring in the "A" pit at Byrapur has been chemically analysed and it shows the presence of $\mathrm{NiO}$ upto $1.81 \%$ whereas, the nickel content in the bleached serpentinite is in the range of $0.01 \%$ to $0.601 \%$ as determined spectrochemically. A careful field and petrological 
study of the rocks in this area has not shown the presence of any nickel sulphide minerals and hence it is regarded that source of the nickel for these hydrous nickel silicate minerals occurring in this area, is the olivine of the dunite.

Though there is considerable controversy regarding the paragenesis of nickel-bearing micaceous serpentine and chlorites there appears to be a single opinion regarding the origin of hydrous nickel silicates occurring as thin films and encrustations, along the joint cracks. Ross et al. (1923) and Pecora et al. (1949) have suggested that the circulating meteoric water can remove the $\mathrm{Mg}, \mathrm{Ni}$ and $\mathrm{Si}$ from the weathered ultrabasic rocks to deposit them as encrustations along the joints and fault planes. The mode of occurrence of the nickel-bearing hydrous silicates in Byrapur suggests that a similar process might have given rise to these minerals.

\section{ACKNOWLEDGEMENT}

The authors are thankful to Prof. M. S. Sadashivaiah, Head of the Department of Geology, Karnatak University, Dharwar, for providing facilities to undertake this work. One of the authors (S. G. Phene) is thankful to the U.G.C. for having provided a Research Fellowship. The authors are indebted to Mr. M. Raichult of the Charles University, Prague, for kindly taking the X-ray powder photographs.

\section{REFERENCES}

Faust, G. T.

.. "The hydrous nickel magnesium silicates-the garnierite group," Amer. Mineral, 1966, 51, 279-98.

Montoya, J. W. and Baur, G. S. "Nickeliferous serpentines, chlorites and related minerals found in two lateritic ore," Ibid., 1963, 48, 1227-38.

Naganna, C.

"Garnierite from Byrapur chromite mines, Mysore State," Bull. Geol. Soc. India, 1965, 2, 65-67.

Pecora, W. T., Hobbs, S. W. and Murata, K. J.

"Variations in garnierite from the nickel deposit near Riddle, Oregon," Econ. Geol., 1949, 44, 13-23.

Ross, C. S., Shannon, F. A. and Gonyer, P. A.

"Origin of nickel silicates at Webster, North Carolina," Ibid., 1928, 23, 528-52. 